Ann. Biol. anim. Bioch. Biophys., 1978, 18 (6), 1279-1292.

\title{
Sertoli cell ultrastructure. I. A comparative study in immature, pubescent, adult and cryptorchid pigs
}

\author{
par Michelle CHEVALIER
}

\author{
Laboratoire de Biologie cellulaire et génétique, \\ Complexe Scientifique des Cézeaux, \\ B. P. 45,63170 Aubière, France.
}

Summary. Sertoli cells of immature pig appeared as a monomorphic cell population. Their cytoplasm contained abundant smooth ER and numerous ribosomes. Sertoli cell junctions began to appear at 6 weeks. In mature testicular tubules two types of Sertoli cells have been identified : typical Sertoli cells (A) with a light nucleus, and other cells (B) with a dark nucleus. A-cells extended from the basement membrane of the tubule to the lumen and showed the same fine structure as in other mammalian species (numerous filaments and ribosomes, abundant smooth ER, parallel-oriented microtubules, Charcot-Böttcher's crystalloids and typical junctions between adjacent Sertoli cells and with germ cells). B-cells had a limited cytoplasm containing smooth ER and numerous filaments. The two types of Sertoli cells were easily characterized by the presence of a large lipid droplet. In cryptorchid testis there were several types of Sertoli cells. The light ones were poor in organelles; the others resembled typical mature Sertoli A-cells but contained many microtubules and CharcotBöttcher's crystalloids which formed large complexes. Well characterized B-cells were not found but some cells similar to them were noted.

\section{Introduction.}

For a long time the Sertoli cell was considered as only having nutritive (Elftman, 1963 ; Fouquet, 1968) and phagocytic (Clegg and Mac Millan, 1965 ; Reddy and Svoboda, 1967 ; Carr et al., 1968 ; Sapsford ef al., 1969) functions. Recently, other activities have been observed indicating that these cells play a key role in male sexual functions, i. e. establishment of a blood-testis barrier due to specialized junction systems (Dym and Fawcett, 1970 ; Fawcett ef al., 1970 ; Dym, 1973 ; Vitale et al., 1973), production of an androgen-binding protein (ABP) (Hansson ef al., 1973 ; French and Ritzen, 1973) and of a protein regulating FSH secretion (inhibin) (Steinberger and Steinberger, 1976). The idea of a steroid hormone-producing Sertoli cell is not new. Recent works show that this cell has enzymatic activity permitting the transformation of testosterone into dihydrotestosterone, androstenedione and androstanediols (Dorrington and Fritz, 1975 ; Tence and Drosdowsky, 1976 ; Welsh and Wiebe, 1976) and the conversion of testosterone into 17 $\beta$-estradiol (Dorrington and Armstrong, 1975). Moreover, this cell may also transform progesterone into testosterone (Christensen and Mason, 1965 ; 
Lacy et al., 1969 ; Hall et al., 1969 ; Tence and Drosdowsky, 1976). The physiological meaning of these syntheses has not been elucidated. The Sertoli cell ultrastructure of several adult mammals is known. Some authors have been more interested in typical formations such as intercellular junctions and Charcot-Böttcher's crystalloids. The Sertoli cell junctions joining adjacent Sertoli cells were principally described by Brökelmann (1963), Nicander (1967), Flickinger and Fawcett (1967), Dym and Fawcetf (1970), Dierichs and Wrobel (1975), Bigliardi and Vegni Talluri (1976), Gilula et al. (1976), Russell (1977a) and Connell (1978); those joining Sertoli cells to germ cells were reported by Ross $(1976,1977)$, Ross and Dobler (1975), Wrobel and Dierichs (1975) and Russell $(1977 a, b, c)$. Charcot-Böttcher's crystalloids have been studied by Bawa (1963), Nagano (1966, 1968), Sohval ef al. (1971) and Toyama (1975).

In this report, a comparative description of the Sertoli cell in immature, pubescent, adult and cryptorchid pigs is presented. The ultrastructure of this cell has been described in immature pig by Dierichs and Wrobel (1975) and Wrobel and Dierichs (1975) and in the boar by Osman and Plöen (1978); that of Charcot-Böttcher's crystalloids in the adult and cryptorchid pig by Toyama (1975).

\section{Maferial and methods.}

Pigs of the Large White breed (Sus crofa L.) were used. Twelve immature 6-week old animals, 4 pubescent 8 -month old ones and 2 adults about 2 years old were studied. Moreover, abdominal testes were taken from unilateral cryptorchid pigs about 8 months old. These testes presented varying degrees of regression and weighed between

\section{PLATE ।}

Ultrastructure of the Sertoli cell in immature pig testis (6 weeks)

(d : densification, DL : desmosome-like junction, ER : smooth endoplasmic reticulum, G : germ cell, IG : interchromatin granules, L : lipid droplet, Nu : nucleolus, $S$ : Sertoli cell.)

FIG. 1. - General view. Note regular oultine of nuclei, large masses of compact chromatin and supranuclear position of lipid droplets. $\times 10000$.

FIG. 2. - Prominent nucleolar complex : nucleolus is flanked by 2 lateral spheres of chromatin (asteriks). $\times 20500$.

FIG. 3. - Golgi apparatus grouping several dictyosomes. Note presence of coated vesicles (arrows). $\times 14000$.

FIG. 4. - Group of dark droplets. $\times 60000$.

FIG. 5. - Smooth ER in apical cell region. Note abundance of ribosomes $\times 20800$.

FIG. 6. - Junctions between 2 Sertoli cells. The dense material on plasma membrane is accompanied by cisternae of smooth ER oriented parallel to cell boundary. The region is rich in microfilaments. $\times 57500$.

FIG. 7. - Desmosome-like junctions between a Sertoli cell and a germ cell. $\times 63000$. 


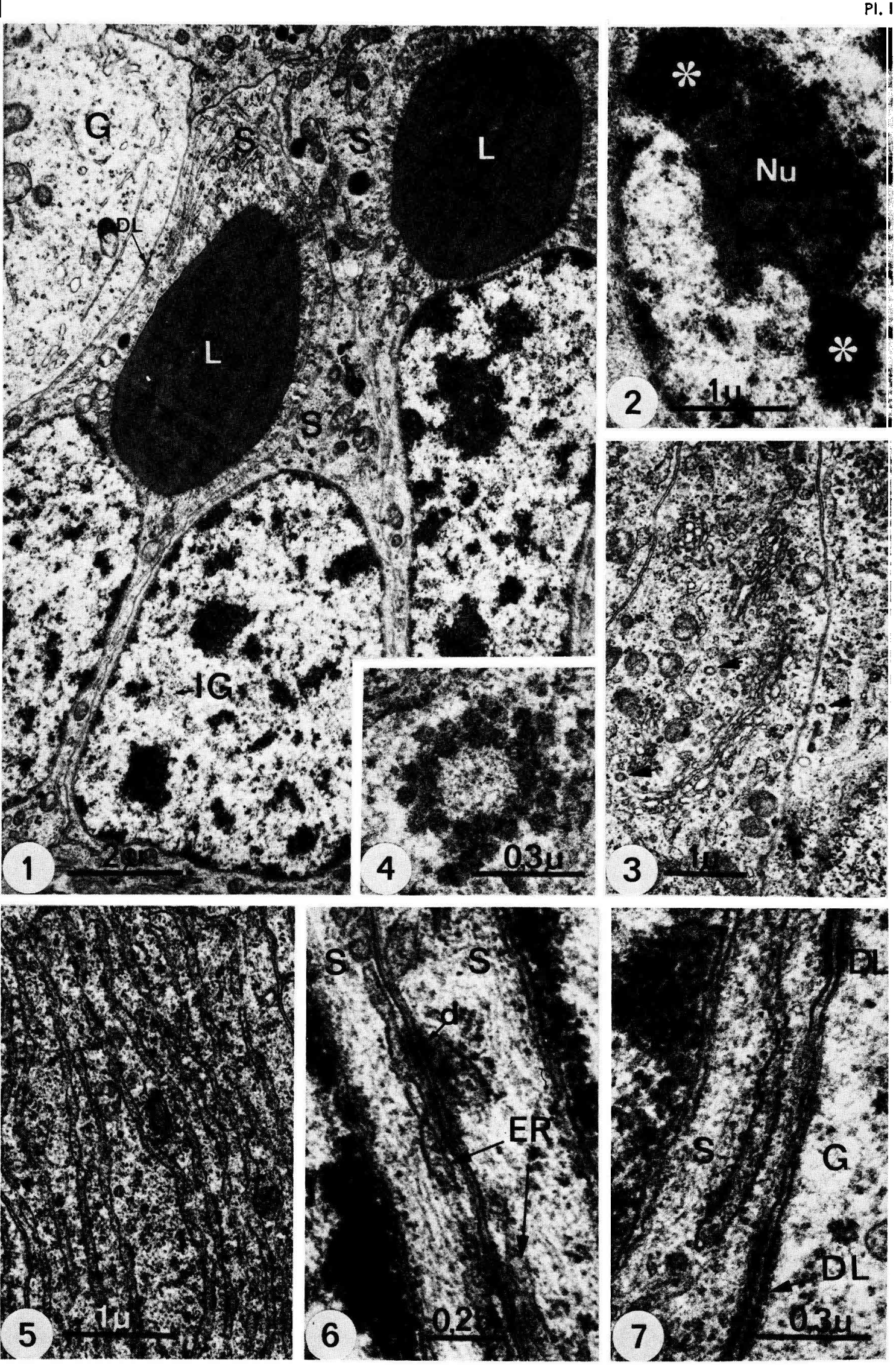


95 and $280 \mathrm{~g}$ (Dufaure ef al., 1971). The samples were taken in the external region of the testis at castration or at slaughter. The testicular fragments were fixed by 2 p. 100 glutaraldehyde in $0.1 \mathrm{M}$ Sörensen's phosphate buffer at $\mathrm{pH} 7.2$ for 20 min., postfixed in 1 p. 100 osmic acid in the same buffer with 4.5 p. 100 sucrose added for $1 \mathrm{hr} .30 \mathrm{~min}$., embedded in epon and cut with a LKB ultramicrotome. The sections were contrasted with alcoholic uranyl acetate and lead citrate. Observations were done with an $80 \mathrm{KV}$ JEM 100 B electron microscope.

\section{Observations.}

6-week old animals. - Sertoli cells are all identical (PI. I, fig. 1) and juxtaposed on the internal edge of the seminiferous cord ; they are joined by lateral junctions. The apical regions are already forming numerous extensions.

The nucleus is always basal (PI. I, fig. 1) and elongated. If has a regular shape ; its internal membrane is accompanied by a discontinuous fringe of compact chromatin. The nucleoplasm is nof dense and contains dispersed chromatin and some large masses of compact chromatin. Two spherical masses of diametrically opposed chromatin are associated with the nucleolus (PI. I, fig. 2). A patch of inferchromatin granules is often situated near the nucleolus (PI. I, fig. 1). These granules are about $25 \mathrm{~nm}$ in diameter.

The narrow strip of cytoplasm under the nucleus contains only a few dark-matrix mitochondria with lamellar transversal cristae, some scattered small tubular elements of the smooth and rough endoplasmic reticulum (ER), free or polysome-grouped ribosomes, some small lipid droplets, and near the nucleus, some microfilaments $5 \mathrm{~nm}$ in diameter. Mitochondria of the same type are found in the lateral and apical regions as well as a Golgi apparatus formed by a group of dictyosomes surrounded by numerous coated vesicles (PI. I, fig. 3, arrows), very abundant smooth ER (PI. I, fig. 5) constituted of saccules organized in large concentric circles, many ribosomes (PI. l, fig. 5), a large supranuclear lipid droplet (PI. I, fig. 1), some small primary lysosomes and a group of small dark droplets 50 to $70 \mathrm{~nm}$ in diameter (PI. I, fig. 4). The latter were always arranged in a circle around a homogeneous « matrix ».

\section{PLATE ॥}

Ultrastructure of pubescent and adult pig Sertoli cells.

(DL : desmosome-like junction, ER : smooth endoplasmic reficulum, $G$ : germ cell, IG : interchromatin granules, L : lipid droplet, Ly : lysosome, MF : microfilaments,

MT : microtubules, $R$ : ribosomes, $S$ : Sertoli cell.)

FIG. 1. - Nucleus and perinuclear region of an A-cell. $\times 7500$.

FIG. 2. - General view of a B-cell. Note triangular nucleus, abundant smooth ER and junctions with a germ cell (arrows). $\times 8400$.

FIG. 3. - Piles of smooth ER in an A-cell. $\times 40000$.

FIG. 4. - Cytoplasmic region near the nucleus of an A-cell. Note numerous lysosomes. $\times 12000$.

FIG. 5. - Numerous microtubules near the cellular lateral membrane in an A-cell. $\times 27500$. 
9 - jer19

12.2. 6

5. $3+1+16$

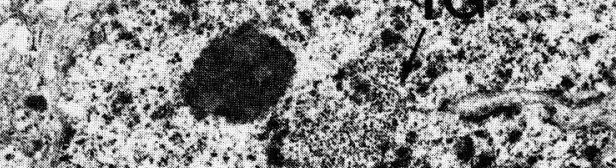

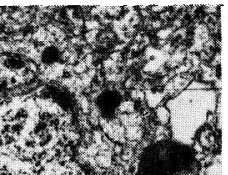

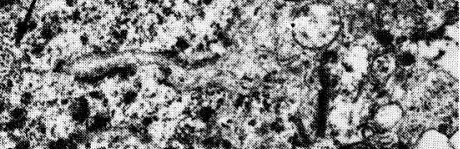

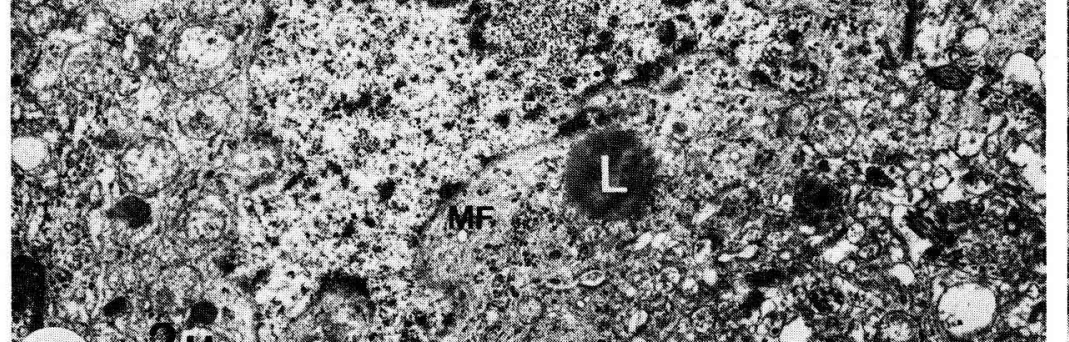
$1.2 \mathrm{~m}$.

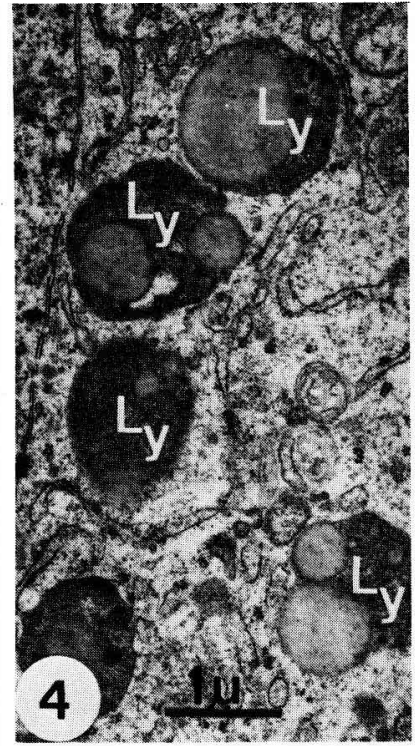

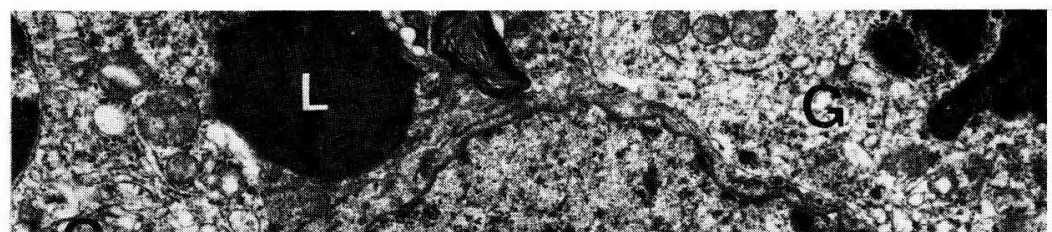

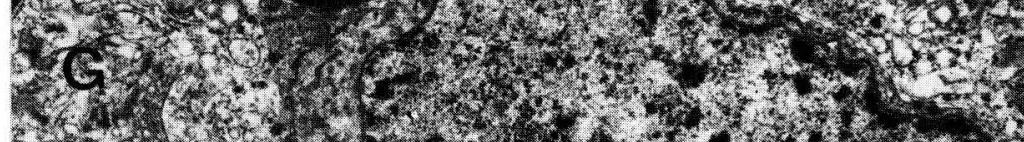

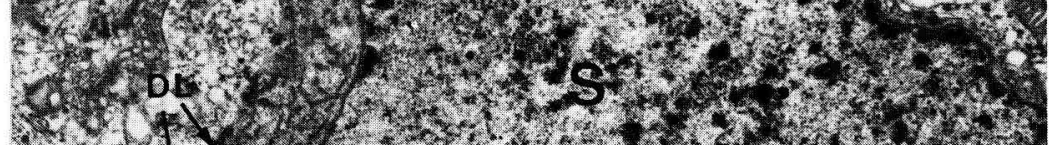

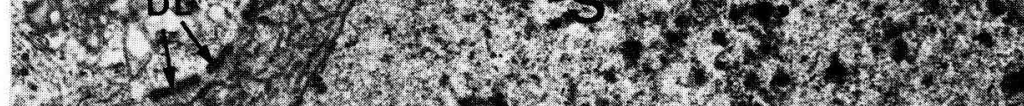


Sertoli cell junctions are seen facing an other Sertoli cell or a germ cell. Between adjacent Sertoli cells there are gap junctions and some formations (PI. I, fig. 6) which develop where the intercellular space narrows from 25 to $10 \mathrm{~nm}$. These formations are the result of a sub-surface modification. The thickness of the plaques formed at the junctional site is about 10 to $20 \mathrm{~nm}$. In some cases these structures are accompanied, on the internal side, by short smooth ER cisternae (PI. I, fig. 6). This region is particularly rich in microfilaments. Desmosome-like junctions are noted facing germ cells (PI. I, fig. 7).

Pubescent and adult animals. - Two types of Sertoli cells (A) (PI. II, fig. 1) and (B) (PI. II, fig. 2), are found. A-cells are more numerous, extending from the basement to the tubule lumen. Their apical region is very irregular. The basal nucleus is elongated (PI. II, fig. 1) and is oriented as in the immature pig. Deep, numerous indentations are observed and the nuclear content is light. Compact chromatin is only found in some small isolated masses. The spheric nucleolus shows no pecularity; it has lost its two masses of associated chromatin. The interchromatin granules are grouped in one or two large patches (PI. II, fig. 1). The nucleus is always surrounded by a cytoplasmic area particularly rich in microfilaments.

In the regions near the nucleus, round or ring-shaped mitochondria are seen having a matrix of variable density; the scarce cristae of these mitochondria are lamellar. The smooth ER is abundant and sometimes in the form of stacks of flat cisternae (PI. II, fig. 3) ; rough ER is rare. Ribosomes and Golgi formations are less numerous than in the immature. Lysosomes vary is size and shape and have a heterogeneous content (PI. II, fig. 4). Microtubules are either isolated or grouped, but always run parallel to the cellular membrane (PI. II, fig. 5). The lipid droplet is not located above the nucleus but laterally (PI. II, fig. 1). The dark droplets of 50 to $70 \mathrm{~nm}$ described

\section{PLATE III}

Stertoli A-cell ultrastructure in pubescent and adult pigs.

(A : acrosome, CR : Charcot-Böttcher's crystalloids, DL : desmosome-like junction, ER : smooth endoplasmic reticulum, $G$ : germ cell, MF : microfilaments, MT : microtubules, $R$ : ribosomes, $S$ : Sertoli cell, SP : spermatid, SSC : subsurface cisternae.)

FIG. 1. - Longitudinal section of Charcot-Böttcher's crystalloids. Some are confluent; one is surrounded by smooth ER. They are located near the lateral cell membrane (arrows). $\times 30000$.

FIG. 2. - Smooth ER opposite the acrosome of an early spermatid. $\times 29000$.

FIG. 3. - Apical region of the cell. Note numerous microtubules and the composition of the Sertoli cell-elongated spermatid junction at spermatid head. $\times 38000$.

FIG. 4. - Cross-section of a specialized Sertoli cell junction. Microfilaments are scattered in groups throughout the plasma membrane (arrows) of every cell; these are accompanied by smooth ER. $\times 42000$.

FIG. 5. - Longitudinal section of specialized Sertoli cell junction. Microfilaments are lined up parallel to the plasma membrane (arrow). $\times 32000$.

FIG. 6. - Sertoli cell junctions in the basal region of the cell. Note smooth ER. $\times 32000$.

FIG. 7. - Desmosome-like junction linking a Sertoli cell to an early spermatocyte. $\times 30000$. 
in the immature are also present. Charcot-Böttcher's crystalloids (PI. III, fig. 1) form electron-dense groups longitudinally striated due to the parallel arrangement of short rectilinear microfilaments. These crystalloids of various sizes and orientations may be confluent. In some cases, they are surrounded by a flat saccule of smooth ER and are usually found near the lateral walls of the cell. The apical cytoplasm contains a large number of microtubules (PI. III, fig. 3), lysosomes, some elongated or ring-shaped mitochondria and piles of smooth ER localized near the acrosomal region of each young spermatid (PI. III, fig. 2).

The specialized Sertoli cell junctions (PI. III, figs. 4, 5) consist of bundles of rectilinear microfilaments running parallel to the plasma membrane of each cell. Deep the layer of microfilaments are elongated cisternae of smooth ER (SSC : sub-surface risternae) which often bear ribosomes on the side toward the cell body. The intercellular space in these structures decreases from about 25 to $10 \mathrm{~nm}$. Other than these formations, there are junctions near the cell base resembling those described in immature animals (PI. III, fig. 6). The Sertoli cells are joined to the sex cells by different systems, depending on the stage of gametogenesis. The early spermatocytes (preleptotene stage) are joined to Sertoli cells by desmosome-like junctions (PI. III, fig. 7). Facing spermatocytes there are also junctions developing only within the Sertoli cell cytoplasm ; these have a microfilamentary structure identical to that of the typical Sertoli cell junctions. These structures are found at different stages of spermatid formation They are first limited to the lateral acrosome regions, and then form a continuous mantle covering the later spermatid head (PI. III, fig. 3). This sheath is composed of microfilaments accompanied on the inner side by elongated cisternae of smooth ER which may contain scattered ribosomes on its surface.

\section{PLATE IV}

Ultrastructure of cryptorchid pig Sertoli cells.

(CR : Charcot-Böttcher's crystalloids, ER : smooth endoplasmic reticulum,

IG : interchromatin granules, L : lipid droplet, MF : microfilaments, MT : microtubules, SSC : subsurface cisternae.)

FIG. 1. - View of a light cell. Note regular-shaped nucleus, few cyłoplasmic organelles. $\times 16000$.

FIG. 2. - An A-cell. Nucleus deeply indented, cytoplasm rich in varied organells. $\times 7000$.

FIG. 3. - Specialized junction linking 2 Sertoli cells. Longitudinal section. $\times 34000$.

FIG. 4. - Superposition of different Sertoli cell junction systems ; towards the base, junctions resemble those seen in the immature (solid arrows); above, typical specialized junctions (open arrows). $\times 10000$.

FIG. 5. - Cross-section of a voluminous Charcot-Böttcher's crystalloid accompanied by smooth ER. $\times 15000$.

FIG. 6. - Higer magnification of a part of the Charcot-Böttcher's crystalloid shown in the perceding figure. $\times 45000$. 


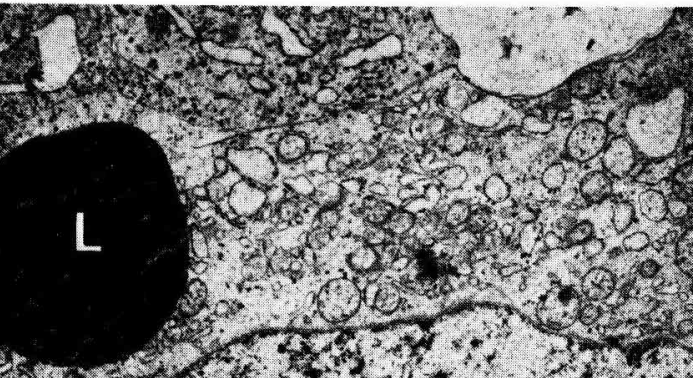

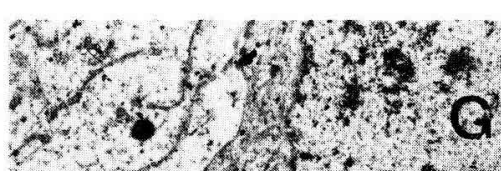

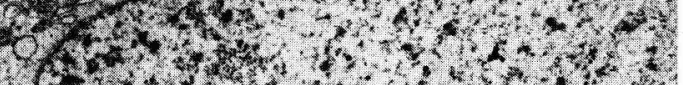
$1.623^{2}+x^{2}$
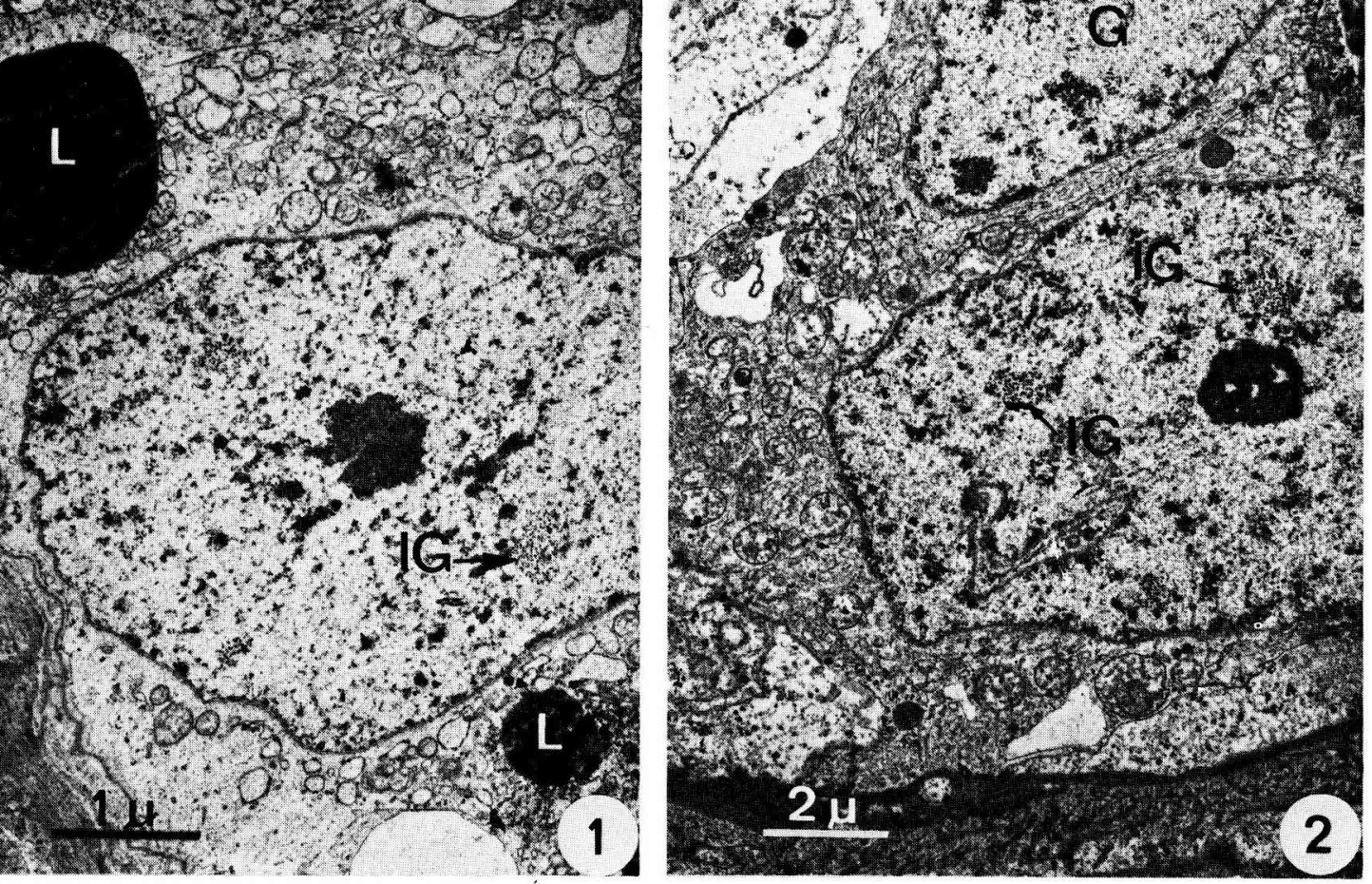
mo

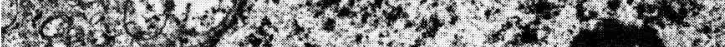

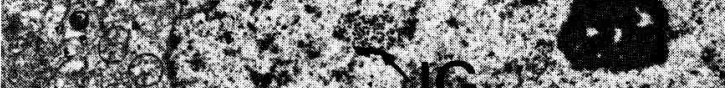

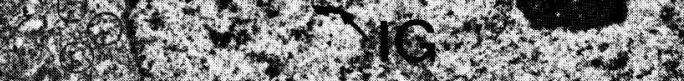

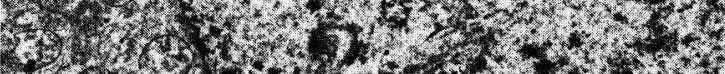

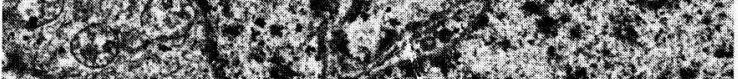

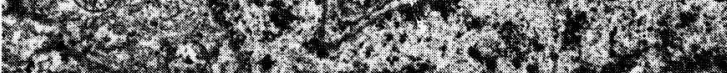

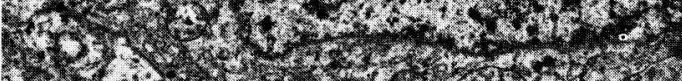

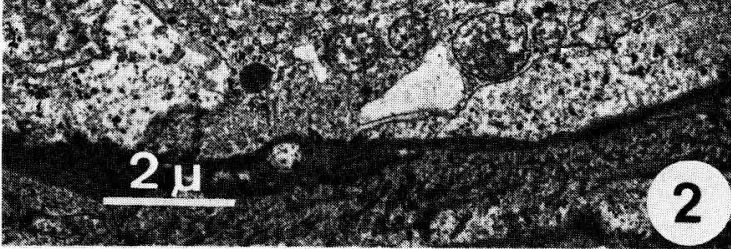

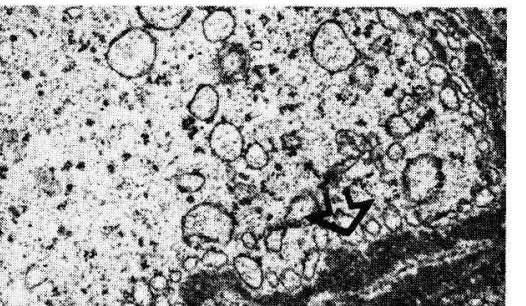

$4: 2$

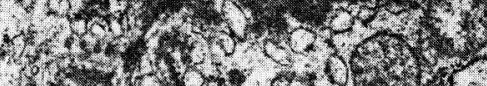

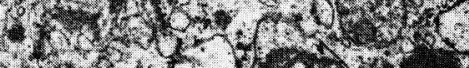
- 3 -

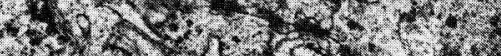

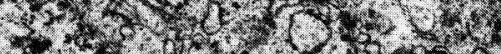

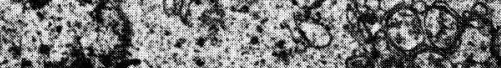

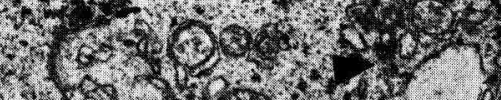

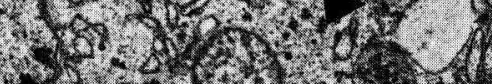

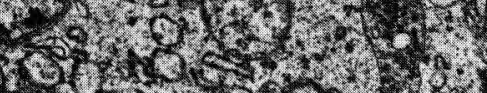
. (8. (3) $x:-2 \times 4$

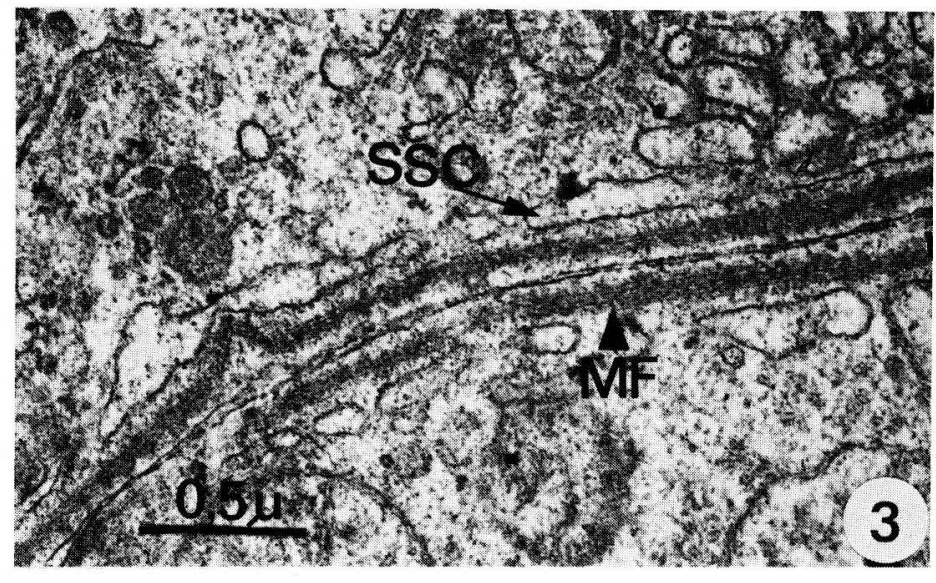

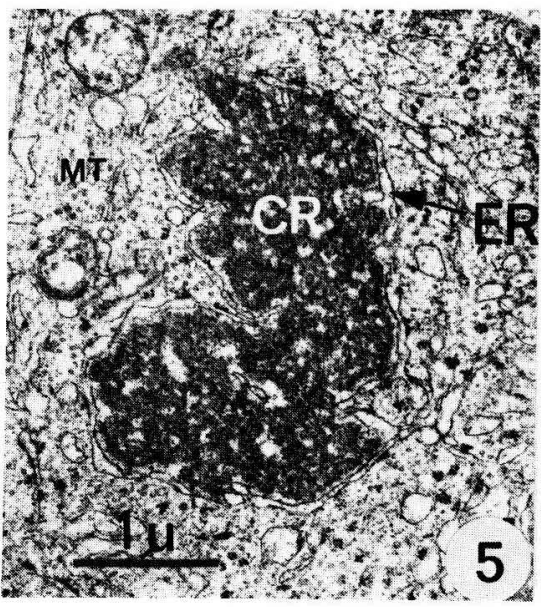

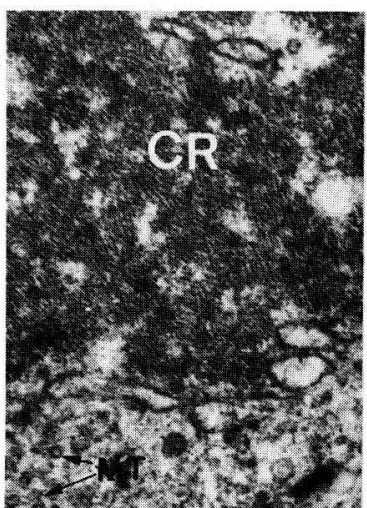

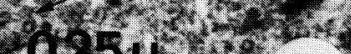
6 
Sertoli B-cells (PI. II, fig. 2) are practically regular and are found only in the basement region of the seminiferous epithelium. The triangular-shaped nucleus is deeply indented ; its content seems more electron-dense than that of the A-cell, although there is the same amount of compact chromatin. Cytoplasm volume is reduced and the cytoplasm contains numerous saccules of smooth ER, some mitochondria with lamellar cristae and a large quantity of unoriented microfilaments. The voluminous lipid droplet is present as in A-cells. Only desmosome-like junctions are observed developing at the early spermatocyte level (PI. II, fig. 2, arrows).

Cryptorchid animals. - Sertoli cells have several aspects. Some present a light hyaloplasm (PI. IV, fig. 1), while other more irregular ones resemble the A-cells noted in the normal mature testis (PI. IV, fig. 2). Although typical B-cells are not found, some cells resemble them in form, surface occupied and nuclear aspect.

The light cells (PI. IV, fig. 1) have a regular outline but the same structure as that of the adult A-cell. The cytoplasm contains smooth ER (sometimes vesicular), a small number of ribosomes and microfilaments and a reduced Golgi apparatus. Microtubules are only found near the lateral membranes of the cell. The same dark droplets observed in the other cases are also seen here. The mitochondria are few and have no pecularity. The lipids form one or two voluminous droplets. The junctions with neighboring Sertoli cells are identical to those of the adult (PI. IV, fig. 3). Between these elements and the cell base we find junctions identical to those described in the immature (PI. IV, fig. 4).

The cells corresponding to A-cells have two pecularities: abundant microtubules (PI. IV, fig. 5) and numerous Charcot-Böttcher crystalloids; the latter may sometimes form a very voluminous aggregate (PI. IV, figs. 5, 6), but are of the same structure.

\section{Discussion.}

The adult pig has a heterogeneous Sertoli cell population composed of two morphological cell types : A-cells, which are more numerous, and B-cells. A-cell nuclei, by their position, shape and chromatin, resemble those described in other species of mammals (Bawa, 1963 ; Brökelmann, 1963 ; Nagano, 1966 ; Dym, 1973, 1974 ; Fawcett, 1975). The configuration of the nucleolus is simpler than reported in rodents and ruminants (Fawcett, 1975) and in our observations under other physiological conditions (immature and hypophysectomized animals).

As in other species, the rough ER is limited to the basal part of the cell. In its smooth form, it occupies a considerable place and toward the interior of the cytoplasm constitutes large figures. The abundance of this organelle in pig, as in other mammals (Nagano, 1966 ; Dym, 1973 ; Fawcett, 1975), may be related to Sertoli cell steroid hormone production (Dorrington and Fritz, 1975 ; Dorrington and Armstrong, 1975 ; Tence and Drosdowsky, 1976 ; Welsh and Wiebe, 1976), the smooth ER being known to contain steroidogenic enzymes (Tamaoki, 1973). The smooth ER is also localized in the region adjacent to the developing acrosome in early spermatids; at that level it is less concentrated than noied in some species of artiodactyls and rodents (Fawcett, 1975). The smooth ER is always present in the specialized intercellular Sertoli-Sertoli and Sertoli-spermatid junctions, but its role is not known.

Lysosomes attest to the phagocytic action of Sertoli cells on degenerating germ cells and residual bodies (Sapsford et al., 1969 ; Black, 1971). A group of dark, regular- 
shaped droplets was mentioned whose nature is unknown; their constant presence must have meaning and requires further study. Bawa (1963) described identical figures in man.

The lipids form a voluminous droplet characteristic of this species and of a wild African pig Phacochaerus aethiopicus (Fawcett, 1975). Some authors interpret Sertoli lipids as a residue of Sertoli phagocytic action (Lacy et al., 1969). This hypothesis was also studied by Sapsford ef al. (1969) with several slight differences. It should be noted that in the pig, this lipid droplet is found at the earliest stages before any spermatogenesis occurs. Lacy suggests that the droplets are used again to synthesize a substance acting on spermatogenesis (Lacy ef al., 1969). Such lipid droplets are also regularly found in steroidogenic cells where they represent cholesterol pools (Sand ef al., 1972).

The role of microtubules, particularly abundant in many species (Brökelmann, 1963 ; Bawa, 1963 ; Christensen, 1965 ; Flickinger, 1967 ; Dym, 1973) was for a long time limited to that of a rigid cellular cytoskeleton. According to Russell (1977b), microtubules participate in germ cell progression, then serve in remodelling the cell.

Charcot-Böttcher's crystalloids were reported by Bawa (1963), Nagano (1966) and Sohval et al. (1971) in adult man and Toyama (1975) in the boar. According to Toyama, these structures result from microfilament overproduction in the basal cytoplasm. The crystalloids then migrate and aid in forming specialized junctions. Present observations agree with this hypothesis because the crystalloids are found near the plasma membrane, oriented in a way foreshadowing the formation of specialized Sertoli cell junctions.

The description of these junctions in pig (Toyama, 1975), rat (Gilula ef al., 1976) and dog (Connell, 1978) is comparable to those of the present study. Toyama (1976) proved that microfilaments found in the junctions were composed of a substance similar to actin, thus indicating that they could play on active role in sex cell displacement (Toyama, 1976 ; Gilula ef al., 1976 ; Nagano and Suzuki, 1976). Junctions between Sertoli cells and germ cells were reported by Ross and Dobler (1975) and by Russell $(1977 a, b, c)$. They observed on one hand desmosome-like junctions with early germ cells, and on the other characteristic junctions with spermatids; these latter were termed as « ectoplasmic specialization ». The same formations were observed in the boar.

B-cells are rare, but are easily distinguishable by their morphology and special situation. Although of reduced volume, their cytoplasm contains elements already noted in A-cells and often considered as characteristic of steroidogenic cells (smooth $E R$, lipid droplet). These cells are not degenerative.

Sertoli cell maturation may be estimated using two criteria : distribution of nucleolar material and establishment of specialized junctions. At birth in the mouse, the nucleolus is associated to the nuclear membrane ; at maturity, a nucleolar complex is formed containing 3 elements : a nucleolar body flanked by 2 chromatin satellites. In the pig we found this structure in immature, but not in pubescent animals. On the other hand, it is seen in the hypophysectomized pigs (Chevalier, in progress). Nucleolar evolution in relation to physiological state will be discussed later. The barrier formed by specialized Sertoli cell junctions does not exist at birth (Vitale et al., 1973 ; Nagano and Suzuki, 1976). The only junctions reported in the newborn are gap junctions; the number of these decreases progressively as that of typical Sertoli junctions increases. 
This process occurs between days 16 and 19 in rat and mouse. In the pig, we could not determine the date this barrier was established. The immature 6-week old pig presents gap junctions and another junction type indicating that the barrier is in the process of forming.

The study of abdominal testes entirely or partially free of sex cells agrees with that of Gilula ef al. (1976). These authors showed that Sertoli cell maturation does not result from inferaction with sex cells since the testis barrier is found in young rat seminiferous tubules containing no germ cells. Considerable development of CharcotBöttcher's crystalloids has been reported in cryptorchid pig (Toyama, 1975). This author supposes that these structures, which in the normal animal contribute to the development of specialized junctions, no longer serve a purpose and thus accumulate. This hypothesis contradicts the fact that specialized junctions in cryptorchid animals develop normally.

The presence of two morphological cell types has already been reported in man (Johnsen, 1969 ; Wartenberg, 1978), prepubescent pig (Wrobel and Dierichs, 1975) and rat in in vitro conditions (de Martino ef al., 1977). The latter authors do not interpret this result. On the other hand, Wartenberg (1978) supposes a different embryonic origin and opposite roles in the control of meiosis (induction and repression). The Aand B-cells defined by Johnsen (1969) using histochemical methods seem to correspond, respectively, to the cells to which we have given the same names. That author shows their existence in young human, adult human and in subjects suffering from different spermatogenetic disorders. Two cell types were not found in the young 6-week old pig. In the cryptorchid animal, on the contrary, cell polymorphism was evident. These variations, apparently related to different physiological conditions, should be studied in the light of Wartenberg's hypothesis.

In conclusion, the type A Sertoli cell in normal adult pig has the main ultrastructural characteristics found in other mammalian species. It will be fascinating to discover the meaning of the existence of the two morphological cell types. Different experimental models will be used to study this problem. We will present the ultrastructure of the hypophysectomized pubescent pig Sertoli cell in a future report.

Reçu en février 1978.

Accepté en mai 1978.

Résumé. Chez le jeune, toutes les cellules de Sertoli sont morphologiquement identiques. Elles contiennent un RE lisse abondant et de nombreux ribosomes. Les premières jonctions spécialisées (Sertoli-Sertoli) sont en cours de formation à 6 semaines.

Il existe chez le pubère et l'adulte deux formes de cellules de Sertoli. Les cellules de Sertoli typiques (cellules $A$ ) ont un noyau clair allongé. Elles s'étendent de la base du tube à la lumière et leur structure est identique à celle décrite chez d'autres espèces (nombreux microfilaments et ribosomes, RE lisse abondant, microtubules orientés parallèlement, cristalloïdes de Charcot-Böttcher, jonctions spécialisées). Les autres cellules (cellules B) sont moins hautes avec un noyau sombre de forme triangulaire et un cytoplasme de volume réduit contenant du RE lisse et de nombreux microfilaments. Les deux types de cellules sont caractérisés par la présence d'un volumineux globule lipidique.

Plusieurs formes de cellules sont décelables chez le cryptorchide, Des cellules claires dont la plupart des organites se sont raréfiés. Des éléments assimilables aux cellules $\mathrm{A}$ de l'adulte mais avec une grande quantité de microtubules et des cristalloïdes de CharcotBöttcher qui peuvent former des structures très importantes. Les cellules de type B n'existent pas mais quelques éléments les rappellent par leur volume et l'aspect de leur noyau. 


\section{References}

BAWA S. R., 1963. Fine structure of the Sertoli cell of the human testis. J. Ulitrast. Res., 9, 459-474.

BIGLIARDI E., VEGNI TALLURI M., 1976. Ultrastructural details of Sertoli cell junctional complexes in vivo and their modifications in tissue culture. Cell Tissue Res., 172, 29-38.

BLACK V. H., 1971. Gonocytes in fetal guinea-pig testes : phagocytosis of degenerating gonocytes by Sertoli cells. Am. J. Anat., 131, 415-426.

BRESSLER R. S., 1976. Dependence of Sertoli cell maturation on the pituitary gland in the mouse. Am. J. Anat., 147, 447-456.

BRÖKELMANN J., 1963. Fine structure of germ cells and Sertoli cells during the cycle of the seminiferous epithelium in the rat. Z. Zellforsch., 59, 820-850.

CARR I., CLEGG E. J., MEEK G. A., 1968. Sertoli cells as phagocytes : an electron microscopic study. J. Anat. G. B., 102, 501-509.

CHRISTENSEN A. K., 1965. Microtubules in Sertoli cells of the guinea pig testis. Anat. Rec., 151, 335.

CHRISTENSEN A. K., MASON N. R., 1965. Comparative ability of seminiferous tubules and interstitial tissue of rat testes to synthesize androgens from progesterone-4-14 $\mathrm{C}$ in vitro. Endocrinology, 76, 646-656.

CLEGG E. J., Mac MILLAN E. W., 1965. Uptake of vital dyes and particulate matter by the Sertoli cells of the rat testis. J. Anat., 99, 219-229.

CONNELL C. J., 1978. A freeze-fracture and lanthanum tracer study of the complex junction between Sertoli cells of the canine testis. J. Cell. Biol., 76, 57-75.

DIERICHS R., WROBEL K. H., 1975. Membranspezialisierungen bei Sertolizellen des Schweines. Verh. anat. Ges., 69, 845-847.

DORRINGTON J. H., ARMSTRONG D. T., 1975. Follicle stimulating hormone stimulates estradiol$17 \beta$ synthesis in cultured Sertoli cells. Proc. Nat. Acad. Sci., USA, 72, 2677-2681.

DORRINGTON J. H., FRITZ I. B., 1975 . Cellular localization of $5 \alpha$ reductase and $3 \alpha$-hydroxysteroid-dehydrogenase in the seminiferous fubule of the rat testis. Endocrinology, 96, 879-889.

DUFAURE J. P., MORAT M., CHEVALIER M., 1971. Ultrastructure et activité steroïdo-déshydrogénasique du testicule de porc cryptorchide. Comparaison avec le testicule de verrat. $C$. $R$. Soc. Biol., 165, 256-289.

DYM M., 1973. The fine structure of the monkey (Macaca) Sertoli cell and its role in maintaining the blood-testis barrier. Anot. Rec., 175, 639-656.

DYM M., 1974. The fine structure of monkey Sertoli cells in the transitional zone at the junction of seminiferous tubules with the tubule recti. Am. J. Anat., 140, 1-26.

DYM M., FAWCETT D. W., 1970. Observations on the blood-testis barrier of the rat and on the physiological compartmentation of the seminiferous epithelium. Biol. Reprod., 3, 308-326.

ELFTMAN H., 1963. Sertoli cells and testis structure. Amer. J. Anat., 113, 25-33.

FAWCETT D. W., 1975. Ultrastructure and function of the Sertoli cell 21-55. In ASTWOOD V. E. B., GREEP R. O., Handbook of Physiology, Vol. 5, sect. 7, Endocrinology. Am. Physiol. Soc., Washington, D. C.

FAWCETT D. W., LEAK L. V., HEIDGER P. M. Jr., 1970. Electron microscopic observations on the structural components of the blood-testis barrier. J. Reprod. Fert., suppl, 10, 105-122.

FLICKINGER C. J., 1967. The postnatal development of the Sertoli cells of the mouse. Z. Zellforsch., 78, 92-113.

FLICKINGER C. J., FAWCETT D. W., 1967. The junctional specializations of Sertoli cells in the seminiferous epithelium. Anat. Rec., 158, 207-222.

FOUQUET J. P., 1968. Etude infrastructurale du cycle du glycogène dans les cellules de Sertoli du hamster. C. R. Acad. Sci., 266, 545-548.

FRENCH, F. S., RITZEN E. M., 1973. Androgen binding protein in efferent duct fluid of rat testis. J. Reprod. Fertility, 32, 479-483.

GILULA N. B., FAWCETT D. W., AOKI A., 1976. The Sertoli cell oceluding junctions and gap junctions in mature and developing mammalian testis. Develop. Biol., 50, 142-168.

HALL P. F., IRBY D. C., KRETSER D. M. de, 1969. Conversion of cholesterol to androgens by rat testes : comparison of interstitial cells and seminiferous fubules. Endocrinology, 84, 488-496.

HANSSON V., MELEAN W. S., SMITH A. A., TINDALL D. J., NAYFEH S. N., FRENCH F. S., RITZEN E. M., 1973. Androgen receptors in rat testis differenf from testicular androgen binding protein (ABP). J. intern. Res. Commun., 1, 27. 
JOHNSEN, S. G., 1969. Two types of Sertoli cells in man. Acta endocr., 61, 111-116.

LACY D., VINSON G. P., COLLINS P., BELL J., FYSON P., PUDNEY J., PETTITT A. J., 1969. The Sertoli cell and spermatogenesis in mammals, 1019-1029. In : Progress in endocrinology. Proc. 3rd int. Congr. Endrocrinol, Mexico, City, 1968.

MARTINO C. de, MARCANTE M. L., FLORIDA A., CITRO G., BELlOCCI M., CANTAFORA A., NATALI P. G., 1977. Sertoli cells of adult rats in vitro. A morphologic and functional study. Cell Tiss. Res., 176, 69-90.

NAGANO T., 1966. Some observations on the fine structure of Sertoli cell in the human testis. $Z$. Zellforsch., 73, 89-106.

NAGANO T., 1968. Fine structural relation between the Sertoli cell and the differentiating spermatid in the human testis. Z. Zellforsch., 89, 39.43.

NAGANO T., SUZUKI F., 1976. The postnatal development of the junctional complexes of the mouse Sertoli cells as revealed by freeze fracture. Anat. Rec., 185, 403-417.

NICANDER L., 1967. An electron microscopical study of cell contracts in the seminiferous tubules of some mammals. Z. Zellforsch., 83, 375-397.

OSMAN D. I., PLÖEN L., 1978. The ultrastructure of Sertoli cells in the boar. Int. J. Andrology, 1, 126179.

REDDY J. K., SVOBODA D. J., 1967. Lysosomal activity in Sertoli cells of normal and degenerating seminiferous epithelium of rat testis. An ultrastructural and biochemical study. Amer. J. Pathol., 51, 1-17.

ROSS M. H., 1976. The Sertoli cell junctional specialization during spermiogenesis and at spermiation. Anat. Rec., 186, 79-103.

ROSS M. H., 1977. Sertoli-Sertoli junctions and Sertoli-spermatid junctions after efferent ductule ligation and lanthanum treatment. Am. J. Anot., 148, 49-56.

ROSS M. H., DOBLER J., 1975. The Sertoli cell junctional specializations and their relationship to the germinal epithelium as observed after efferent ductule ligation. Anat. Rec., 183, 267-292.

RUSSELL L., 1977a. Movement of spermatocytes from the basal to the adluminal compartment of the rat testis. Am. J. Anat. 148, 313-328.

RUSSELL L., 1977b. Observations on rat Sertoli ectoplasmic ('Junctional') specialization in their association with germ cells of the rat testis. Tissue Cell., 9, 475-498.

RUSSELL L., 1977c. Desmosome-like junctions between Sertoli and germ cells in the rat testis. Am. J. Anat., 148, 301-312.

SAND G., FRUHLING J., PENASSE W., CLAUDE A., 1972. Distribution du cholestérol dans la cortico surrénale du rat : analyse morphologique et chimique des fractions subcellulaires isolées par centrifugation différentielle. J. Microscopie, 15, 41-66.

SAPSFORD C. S., RAE C. A., CLELAND K. W., 1969. The fate of residual bodies and degenerating germ cells and the lipid cycle in Sertoli cells in the bandicoot Perameles nasufa Geoffroy (Marsupialia). Austral., J. Zool., 17, 729-753.

SOHVAL A. R., SUZUKI Y., GABRILOVE J. L., CHURG J., 1971. Ultrastructure of crystalloids in spermatogonia and Sertoli cells of normal human testis. J. Ulitrastruct. Res., 34, 83-102.

STEINBERGER A., STEINBERGER E., 1976. Secretion of an FSH-inhibiting factor by cultured Sertoli cells. Endocrinology, 99, 918-921.

TAMAOKI B. I., 1973. Steroidegenesis and cell structure. Biochemical pursuit of rites of steroid biosynthesis. J. Steroid Biochem., 4, 89-118.

TENCE H., DROSDOWSKY M., 1976. Biosynthesis and metabolism of testosterone by Sertoli cell enriched seminiferous fubules. Biochem. biophys. Res. Commun., 73, 47-55.

TOYAMA Y., 1975. Ultrastructural study of crystalloids in Sertoli cells of the normal intersex and experimental cryptorchid swine. Cell Tissue Res., 158, 205-213.

TOYAMA Y., 1976. Actin-like filaments in the Sertoli cell junctional specializations in the swine and mouse testis. Anat. Rec., 186, 477-492.

VITALE R., FAWCETT D. W., DYM M., 1973. The normal development of the blood-testis barrier and the effects of clomiphene and estrogen treatment. Anat. Rec., 176, 333-344.

WARTENBERG H., 1978. Human testicular development and the role of the mesonephros in the origin of a dual Sertoli cell system. Andrologia, 10, 1-21.

WELSH M. J., WIEBE J. P., 1976. Sertoli cells from immature rats : In vitro simulation of steroids metabolism by FSH. Biochem. Biophys. Res. Commun., 69, 936-941.

WROBEL K. H., DIERICHS R., 1975. Wachstum and Differenzierung der Sertolizellen im Schweine hoden wahrend des postnatalen Ontogenese. Anat. Anz., 69, 723-724. 